\title{
Characteristics of Miscarriages in West Lombok District, West Nusa Tenggara
}

\author{
I P A Winata ${ }^{1}$ and S Harkitasari ${ }^{1 *}$ \\ ${ }^{1}$ Faculty of Medicine and Health Sciences, Universitas Warmadewa, Denpasar, Bali \\ *saktiviharkitasari85@gmail.com
}

\begin{abstract}
Abortion is the end of pregnancy before the age of 20 weeks. Abortion is commonly happened in pregnancy. Abortion can be harmful to the mother and can cause death. Maternal death rate in Indonesia is currently still quite high, reaching 359 per 100,000 live births. The risk factors of abortion are the amount of the workload and maternal age at pregnancy and parity. In this study, the factors that become the determinants in the occurrence of abortion are found. The research was conducted in West Lombok regency, West Nusa Tenggara with cross sectional method and sampling technique using systematic random sampling, there were 64 samples. The data collection is done by distributing questionnaires which are then analyzed by using computer application. The result of this research shows that the majority of abortion patients are at the age of 20-30 years with 17 respondents $(68.00 \%)$, in education category, it shows that the majority of abortion patients in primary, junior high, and senior high school are 26 respondents $(57.78 \%)$. The occupation category also shows more abortion patients in the heavy workload with 22 respondents $(56.40 \%)$ and in parity category, the majority of patients which experienced abortion in two times parity are 18 respondents (54.55\%). It is hoped that health workers will prioritize protective measures and adequate service approach, besides it is expected that the health service center develops a supportive health promotion program.
\end{abstract}

Keyword : Characteristics, Lombok District, Nusa Tenggara.

\section{Introduction}

Abortion is the end of pregnancy before 20 weeks of gestation with fetal weight of less than $500 \mathrm{gr}$ (1). Abortion is the most common occurrence in pregnancy. The incidence of abortion is still high to date. In 2013 there were 673 cases and in 2014 it increased to 793 cases but in 2015 it decreased to 672 cases (2). The maternal mortality rate in Indonesia is currently quite high reaching 359 per 100,000 live births based on the results of the 2012 Indonesian Health Demographic Survey or Survei Demografi Kesehatan Indonesia (SDKI). Maternal mortality in Indonesia is mostly caused by bleeding, preeclampsia, infection, abortion and can be caused by prolonged labor (3). Bleeding during pregnancy can be due to abortion, disrupted ectopic pregnancy and antepartum bleeding. Various efforts have been made to reduce maternal mortality and morbidity, one of which is through the Millennium Development Goals (MDGs) by providing antenatal care and childbirth services by trained health personnel, increasing contraceptive use rates and reducing the unmeet meed through improved access and quality of care family planning and reproductive health as well as other efforts, but currently it has not achieved the expected goal of 102 per 100,000 live births (4). Based on Local Area Monitoring Data or Pemantauan Wilayah Setempat (PWS) KIA of West Lombok in 2015 the incidence of abortion was caused by several risk factors, namely, 
maternal age, education, workload and maternal parity. Pregnant women have a high risk of abortion, one of the most influential factors is a heavy workload for pregnant women. Jobs affect one's income. In pregnancy the mother's uterus is stretched by the presence of a fetus. If the women give birth too often, the uterus will become weaker. If the mother has given birth to 4 or more children, it is necessary to watch out for any disturbances during pregnancy, childbirth and puerperium. The risk of spontaneous abortion increases with maternal parity.

In West Lombok, although abortion is not the cause of maternal death cases, the number of cases of abortion has increased every year. Based on the background above, the researchers are interested in finding out what are the determinants of the incidence of abortion in West Lombok Regency, West Nusa Tenggara

\section{Method}

\subsection{Data Collection}

This study used a descriptive research method with cross sectional design to determine the determinants of the abortion incidence in West Lombok District, West Nusa Tenggara. Sources of data in this study are primary data with researchers filling out questionnaires as a result of interviews with respondents.

Variables from this study are age, education, employment and parity. The source of data in this study is primary data with researchers filling out questionnaires as a result of interviews with respondents guided by village midwives in each local area.

\subsection{Statistical Analysis}

Data were analyzed using SPSS. The collected data was then analyzed descriptively using univariate analysis. The results of the analysis are then presented in the form of a frequency table.

\subsection{Ethical Consideration}

The study, the collection of clinical and epidemiological data submitted for ethical approval to the Research Ethic Committee of Udayana University, Denpasar. Enrollment of the study participants is conditional on appropriate consent.

\section{Results And Discussion}

Table 1. Characteristics of research respondents $(n=64)$

\begin{tabular}{lcc}
\hline \multicolumn{1}{c}{ Variable } & Amount & Percentage (\%) \\
\hline Age (years) & 22 & \\
$15-19$ & 3 & 35.48 \\
$20-24$ & 16 & 4.83 \\
$25-29$ & 12 & 25.80 \\
$30-34$ & 6 & 19.35 \\
$35-39$ & 3 & 9.67 \\
$40-45$ & 3.83 \\
\hline
\end{tabular}




\begin{tabular}{lcc}
\hline \multicolumn{1}{c}{ Variable } & Amount & Percentage (\%) \\
\hline Education & & \\
Elementary school & 9 & 14.06 \\
Junior high school & 25 & 17.18 \\
Senior high school/equivalent & 15 & 39.06 \\
Diploma-1 & 4 & 24.43 \\
Diploma-3 & 0 & 6.25 \\
Undergraduate & 0 & 0.00 \\
Postgraduate & 0 & 0.00 \\
Doctoral & & 0.00 \\
Occupation & 22 & \\
Housewife & 1 & 34.75 \\
Office employee & 2 & 1.25 \\
Private employee & 0 & 3.25 \\
Civil servant & 3 & 0.00 \\
Police & 0 & 4.75 \\
Indonesian National Army (TNI) & 25 & 0.00 \\
Traders & 6 & 39.25 \\
Farmer & 5 & 9.75 \\
Laborer & & 7.25 \\
Parity & 14 & \\
1 & 33 & 21.75 \\
2 & & 51.25 \\
\hline
\end{tabular}

Based on Table 1 it can be seen that there are several variables, namely age, education, employment and parity. In the age variable there is a 15-19 year age category having the highest number of respondents 22 people with a percentage (35.48\%) and the age group 40-45 years with the lowest respondents numbering 3 people (4.83\%). In the education variable there is a high school / equivalent education category with the highest number of respondents of 25 people with a percentage (39.06\%), while the lowest in the D3 education category is 4 people with a percentage $(6.25 \%)$. In the employment variable there are occupational categories as housewives and traders with the highest number of respondents, each with 22 people with a percentage $(34.75 \%)$ and 25 people with a percentage $(39.25 \%)$. Finally, there is a variable of parity, it can be seen that the most twice parity category is 33 people with a percentage $(51.25 \%)$.

Table 2. Sample Distribution Based on Age

\begin{tabular}{cll}
\hline \multicolumn{1}{c}{ Variable } & \multicolumn{1}{c}{ Miscarriages f (\%) } & Non-miscarriages f (\%) \\
\hline Age & & \\
$<20$ years old & $7(28.00)$ & $18(72.00)$ \\
20-30 years old & $17(68.00)$ & $8(32.00)$ \\
$>30$ years old & $7(50.00)$ & $7(50.00)$ \\
\hline
\end{tabular}

It can be seen in table 2 of the age categories of the research respondents, that the age of 20-30 years had the highest incidence of abortion with 17 people with a percentage (68.00\%) and at the age of $<20$ years experiencing at least 7 abortions with a percentage $(28,00 \%)$. 
Table 3. Sample Distribution Based on Education Background

\begin{tabular}{|c|c|c|}
\hline Variable & Miscarriages f (\%) & Non-miscarriages $f(\%)$ \\
\hline \multicolumn{3}{|l|}{ Education } \\
\hline Low & $0(0.00)$ & $0(0.00)$ \\
\hline Middle & $26(57.78)$ & $19(42.22)$ \\
\hline High & $5(26.31)$ & $14(73.68)$ \\
\hline
\end{tabular}

In table 3 the education category obtained that the secondary education has the highest incidence of abortion, amounting to 26 people $(57.78 \%)$. At the higher education level, respondents who experienced the least number of abortions were 5 people $(26.31 \%)$.

Table 4. Sample Distribution Based on Occupation

\begin{tabular}{cll}
\hline \multicolumn{1}{c}{ Variable } & \multicolumn{1}{c}{ Miscarriages f (\%) } & Non-miscarriages f (\%) \\
\hline Occupation & & \\
Low-intensity & $9(36.00)$ & $16(64.00)$ \\
High-intensity & $22(56.40)$ & $17(43.60)$ \\
\hline
\end{tabular}

In table 4 , the respondents with high-intensity work had the highest incidence of abortion amounted to 22 people $(56.40 \%)$, and the respondents within the light-intensity category at least experienced an incidence of abortion totaling 9 people $(36.00 \%)$.

Table 5. Sample Distribution Based on Parity

\begin{tabular}{|c|c|c|}
\hline Variable & Miscarriages f $(\%)$ & Non-miscarriages $\mathbf{f}(\%)$ \\
\hline \multicolumn{3}{|l|}{ Parity } \\
\hline 1 & $2(14.14)$ & $12(85.56)$ \\
\hline 2 & $18(54.55)$ & $15(45.45)$ \\
\hline 3 & $11(64.82)$ & $6(35.18)$ \\
\hline
\end{tabular}

In the table 5 of parity categories, obtained that the respondents within category of two parities experienced incidence of miscarriage, with respondents amounted to 18 people $(54.55 \%)$. In the category of one parity had the least miscarriage with the number of respondents of 2 people (14.14\%).

Based on the age category in the study respondents, the age of 20-30 years had the tendency to experience the most incidence of abortion, amounting to 17 respondents $(68.00 \%)$. While the age range $<20$ years and $>30$ years is smaller than the age range of 20-30 years, namely 7 respondents $(28.00 \%)$ and 7 respondents $(50.00 \%)$ respectively. This study is in line with study carried out by Rimonta that in the group of respondents who experienced incomplete abortion, as many as 49 people $(37.69 \%)$ were in the high risk age range $(<20$ years and $>30$ years), smaller than the number of respondents in the low risk age range (20-30 years) of 54 respondents $(41.54 \%)$. The high incidence of abortion in productive age (20-30 years) tends to have higher stress levels, poor food diets and poor lifestyles, trauma due to excessive activity, so that it can be one of the trigger factors for abortion (5) .

This study contradicts the research conducted by Desyanti Dwi which shows that there is a relationship between age and the incidence of abortion in PKU Muhammadiyah General Hospital Bantul in 2016, concluded that mothers at risk ( $<20$ or $>30$ years) are 4 times more at risk of having abortion than mothers with no risk (20-30 years) (6). This study also contradicts the research of Kenneth J. Leveno explaining that at the age of 35 years or older, maternal 
health has declined. As a result, pregnant women at this age are more likely to have premature children, prolonged labor, bleeding and miscarriage. Clinically spontaneous abortion was detected to increase by $12 \%$ in women younger than 20 years and to $26 \%$ in women aged 40 years (7).

Based on the category of education, samples who are elementary, junior high, high school/equivalent graduates has the highest incidence of abortion, amounting to 26 respondents $(57.58 \%)$. This study is in line with what was explained by Pitriani Riza. Pregnant women who are elementary and junior high school studentss are at higher risk of developing incomplete abortion compared to high-educated pregnant women (8). Hartono stated that education greatly influences the frequency of pregnancy rates. An increase in the number of unwanted pregnancies is one indication that understanding of reproductive health is still very minimal (9).

The results of this study are in accordance with the theory by Prawirohardjo mentioning education is needed by humans for one's intellectual development. Intellectual maturity will affect insight and ways of thinking both in action and decision making in making policy related to the utilization of health services. Low education background makes a person careless to health programs so that they do not recognize the dangers that might occur. Although health facilities are available, they are not necessarily willing to use them (10).

Based on the research, high-intensity workers tend to have a higher incidence of abortion, amounting to 22 respondents $(56.40 \%)$. While respondents who had a light occupation category had 9 respondents $(36.00 \%)$. According to Baba in his journal mentioned that women in each type of work have a higher risk of experiencing spontaneous abortion. In this study almost $90 \%$ of mothers had additional workloads as well as being housewives. In mothers with heavy workloads $66 \%$ were farmers, and $27 \%$ are factory workers. Whereas for mothers with additional job while also being housewives, $30 \%$ are civil servants and others have part time jobs such as selling at home and sewing. Increased risk of spontaneous abortion in pregnant women who work is caused by the double burden of housewives as well as career women. Excessive workload on pregnant women can cause fatigue in the mother (11).

According to a study by Lili, explaining that the heavy work carried out by pregnant women is the work that has to be done with extra energy expenditure or with the emancipation of women today, the condition of women or working mothers is often found under any conditions. In Indonesia there are no laws that regulate pregnant women not to work or getting any pregnancy leave, so this also triggers the incidence of abortion in pregnant women who work in jobs that require extra energy or heavy physical burden (12).

According to Kurniasih, the place where women work is very influential on women's reproduction, because if they work in a place that is often exposed to chemicals, radiation and if exposed to these materials it will increase or can cause abortion. In the first trimester, embryonic cells are defined to form an organ system. So chemicals can also inhibit the formation of organs and inhibit the results of conception. The work that must be avoided when pregnant women are farmers, factory workers, work in the laboratory, police, army and traders. In addition, women who work as private employees or civil servants who need a long time to sit also influence the occurrence of abortion because it can cause stress and will weaken physical conditions and interfere with fetal development (13).

The results of this study have similarities with the research conducted by Pitriani stating that working mothers have higher stress levels than mothers who do not work. But the problem is with women's reproduction, because if they work in places where there are many dangerous substances such as chemicals, radiation and if exposed. So that the pregnancy results in mechanical trauma that ends in abortion (14). 
Based on the results of the study, parity of two, tended to have the highest incidence of abortion with 18 respondents $(54.55 \%)$. Whereas at parity 1 and parity 3 , there were 2 respondents $(14.14 \%)$ and 11 respondents $(64.82 \%)$ respectively. This study is in accordance with the theory that Cunnungham explained, that the risk of abortion increases with increasing parity. In pregnancy the mother's uterus will be stretched by the presence of a fetus and the higher parity will cause the uterus to be more vulnerable and risky for miscarriage (15). If the mother has given birth to 4 or more children, any disturbances in pregnancy we should be aware about. This study is also in accordance with research done by Prawirohardjo, who stated that parity 2 and 3 are parities which are at risk and have an impact on maternal mortality (16).

\section{Conclusions}

From this study, researchers found that based on the age variable, the age category of 2030 years old experienced the most miscarriage amounted to 17 abortions, this is because the 20-30 year age group tends to have high stress levels, poor food diets and poor lifestyles. Judging from the education variable, the elementary, junior high and high school education categories/equivalent experienced the highest number of abortions, there were 26 people, this was related to the lack of understanding of the mother's education about abortion. In the employment variable, the category of high-intensity worker experienced the highest incidence of abortion totaling 22 people, this was related to excessive workload which would increase the incidence of abortion. From the parity variable, the parity of two has the highest incidence of miscarriage, amounting to 18 people, this is in accordance with the theory that the risk of abortion increases with increasing parity.

\section{References}

[1] Prawirohardjo, Ilmu Kandungan. Jakarta. Yayasan Bina Pustaka Sarwono Prawirohardjo; 2007

[2] Dinas Kesehatan Kabupaten Lombok Barat, Faktor-faktor Resiko Yang Mempengaruhi Kejadian Abortus Di Kabupaten Lombok Barat Tahun; 2015

[3] Yono, Hubungan Paritas dan Umur Ibu dengan Kejadian Abortus; 2011

[4] Bappenas, Meningkatkan Kesehatan Ibu Tujuan 5 : Meningkatkan Kesehatan Ibu. , pp.57-62; 2010

[5] Febby, Rimonta G. Hubungan Abortus Inkomplit Dengan Faktor Risiko Pada Ibu Hamil Di Rumah Sakit Pindad Bandung Periode 2013-2014. Fakultas Kedokteran Universitas Kristen Maranatha Bandung; 2015

[6] Desyanti, Dwi, Faktor-faktor Yang Berhubungan Dengan Kejadian Abortus Di Rumah Sakit Umum PKU Muhammadiyah Bantul Tahun 2016. PKU Muhammadiyah Bantul; 2017

[7] Leveno KJ, Cunningham FG, Gant NF, Obstetri Williams: Panduan Ringkas. Edisi 21. Jakarta: EG; 2009

[8] Pitriani, R. et al., Factors Associated with Incomplete Abortion in Arifin Achmad General Hospital District Arifin Achmad of Riau Province; 2013

[9] Hartono, Hubungan antara Karanteristik Ibu dan Kejadian Kematian Bayi di Kabupaten Pontianak Provinsi Kalimantan Barat, (Online),(http://www.litbang.depkes.go.id/risbinkes/Buku\%20Laporan\%20Penelitian\%202006 /hubungan\%20karakteristik\%20bumil\%20dan\%20AKI.htm) (pndidikan); 2006 
[10] Prawirohardjo, Sarwono, Pelayanan Kesehatan Maternal dan Neonatal. Yayasan Bina Pustaka: Jakarta; 2010

[11] Baba S, Noda H, Nakayama M, Risk Factor of Early Spontaneous Abortion Among Japanese : a Matched Case-Control Study. Human Reproduction. 2010 Desember 14 ; Vol 26, No.2 pp. 466-472; 2010

[12] Fajria, Lili., Analisis Faktor Resiko Kejadian Abortus Di RSUP Dr. M. Djamil Padang. Fakultas Keperawatan Universitas Andalas; 2013

[13] Nia Kurniasih, R.M., Faktor-faktor Yang Berhubungan Dengan Kejadian Abortus Pada Pekerja Wanita Di pt X Kabupaten Sumedang Provinsi Jawa Barat Tahun 2013. , 25, pp.1-19; 2013

[14] Pitriani, R. et al., Factors Associated with Incomplete Abortion in Arifin Achmad General Hospital District Arifin Achmad of Riau Province; 2013

[15] Leveno KJ, Cunningham FG, Gant NF, Obstetri Williams: Panduan Ringkas. Edisi 21. Jakarta: EG; 2009

[16] Prawirohardjo, Ilmu Kandungan. Jakarta. Yayasan Bina Pustaka Sarwono Prawirohardjo; 2007 